U.A.R. J. Anim. Prod., Vol. 10, No. 2, pp. 233-243 (1970).

\title{
THE INFLUENCE OF VARIATION IN DRY MATTER CONTENT ON VOLUNTARY INTAKE OF WILTED SILAGE
}

\author{
By \\ A.S. El-Seotokshy, aitd J.H.D. Prescoltr, *
}

\begin{abstract}
Calves wor: nfFurs silagn of 39.2 (High) or $36.6 \%$ (Modium) dry

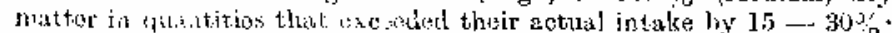
T'lo culves offered tho medium D.M. silage consumed significantly (P) $>0.001)$ more fresh muterial than those of fored the high D.M. sifugg but hat at elightly, though not significaptly, lower intake of dry matter.

firesh intalso inereaied as dry matter pereentage declined but not

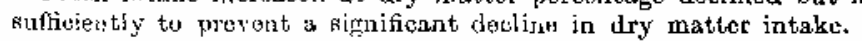

Viariation in siluwe dry mattor intake between individual calves was olosily asocicted with variation in liveweight $\{\mathrm{r}=87-97 \%$ liveweigitt ru:ige it - $237 \mathrm{~kg}$.

Tin calves ensumal dry mitter as high D.M. silage in quantites equivaluot to 2.54 of $_{0}$ of liveweight and us medium D.M. . jlage to $2.35 \%$ 01 tiveweight. 'inis ditterence of $9 \%$ was not siguiticant.
\end{abstract}

There is considerable interest in utilisation of silage for the production of milk and meat. High production from silage can only be obtained when the silage has a high nutritive value and is consumed in large quantities by livestock. In many circumstances intake of silage per se imposes a most important limitation on production.

There is ample evidence that the dry matter intake from silage by ruminants depends on factors related to its digestibility dry matter content, physical state and "palatability" (Moore et al., 1960 ; Thomas et al., 1961; Murdoch, 1966; I'ratt and Conrad, 1967). The relationship between digestibility of silage and the time feed residues are retained in the rumen (Freer et al., 1961) has been used to explain the greater the voluntary intake of high versus low digestibility silage (Murdoch, 1964). Increasing dry matter content of the silage (over the range $30-60 \%$ ) has generally been associated with an increase in voluntary intake of this feed (Gordon et al., 1965; Pratt and Conrad, 1967 ; McCullough, 1961).

It has been demonstrated that under unfavourable condition of fermentation as with material of a high moisture content, butyric acid and the end-products of protein break-down are produced in the silage and have inhibitary effects on silage intake by livestock (Thomas et al., 1961; Morgan, I963).

* Ceneral Organization for Veat, Cairo, U.A.R. Preaent adress : Sobool of Agriculture, University of Newcastle-Upon-Tyne, U.K. 
Cutting herbage at an early stage of maturity, when it has a high digestibility and wilting this herbage to $30-50 \%$ dry matter before ensiling in seared containers produces high quality silage (Pratt and Conrad, 1967). Wilting silage increases the sugar concentration in the herbage and also increases the osmotic pressure potential of this material (Wieringa, 1960). The increase in osmotic pressure of silage produces a decrease in butyric acid production even when the material has a relatively high pH (Wieringa, 1960). The lactic acid concentration in the silage increases as moisture content decreases.

The experiment descibed hereafter was conduicted to investigate the acceptability of Jersey calves to two silages similar in all respects other than dry matter content. These silages were wilted in the field to a variable extent and stored in sealed silos. The medium D.M. silage contained an average slightly more than $35 \%$ dry matter and high D.M. silage rather more than $55 \%$.

\section{Material and Methods}

\section{1.-Experimental design and treatments}

The experiment conformed to a two treatment comparison of change-over design. Fourteen Jersey calves were grouped into seven pairs of similar age liveweight, and one member of each pair was allocated at random to one or other of the experimental treatments. The experiment was organised in two, fifteon-day, feeding periods. During the first period one member of each pair of calves was offered high dry matter silage and the other medium dry matter silage and during the second period each calf was offered the alternative type of silage A description of the two groups of calves and the layout of the experiment is presented in Table 1.

TABLE 1.-DESCRIPTION OF EXPERIMENTAL ANIMAL AND IA YOCT OF EXPERIMENT

\begin{tabular}{|c|c|c|c|c|c|}
\hline \multirow{2}{*}{$\begin{array}{l}\text { Calf } \\
\text { group }\end{array}$} & \multirow{2}{*}{$\begin{array}{l}\text { No. of } \\
\text { calres }\end{array}$} & \multirow{2}{*}{$\begin{array}{c}\text { Mesn age } \\
(\text { daye })\end{array}$} & \multirow{2}{*}{$\begin{array}{c}\text { Mean weight } \\
\text { (kg) }\end{array}$} & \multicolumn{2}{|c|}{ Experimental silage offered } \\
\hline & & & & Period I & Period II \\
\hline $\mathrm{I}$ & 7 & $327 \pm 34.6$ & $170.3 \pm 17.03$ & High & Medium \\
\hline II & 7 & $329 \pm 35.5$ & $163.0 \pm 16.20$ & Medium & Hight \\
\hline
\end{tabular}

U.A.l. J. Anim. Prod., 10, No. 1 (1070). 


\section{2.-Feeds}

The experimental silages were 'second-cut' herbage from a two year old timothy-perennial ryegrass-white clover sward. The grass was wilted and different period of drying and different methods of herbage conditioning were employed in order to obtain two experimental silages uniform in all respects other than dry matter content (Tabe 2). Each type of silage was stored in lined and sealed silos holding from 980 to $1060 \mathrm{kr}$ silage dry matter.

TABI.E 2.- CRUDF PROTHIN, DIGESTIBLE CRUDE PRotein AND in vitro DIGESTIBILITY of the silages and concentrates

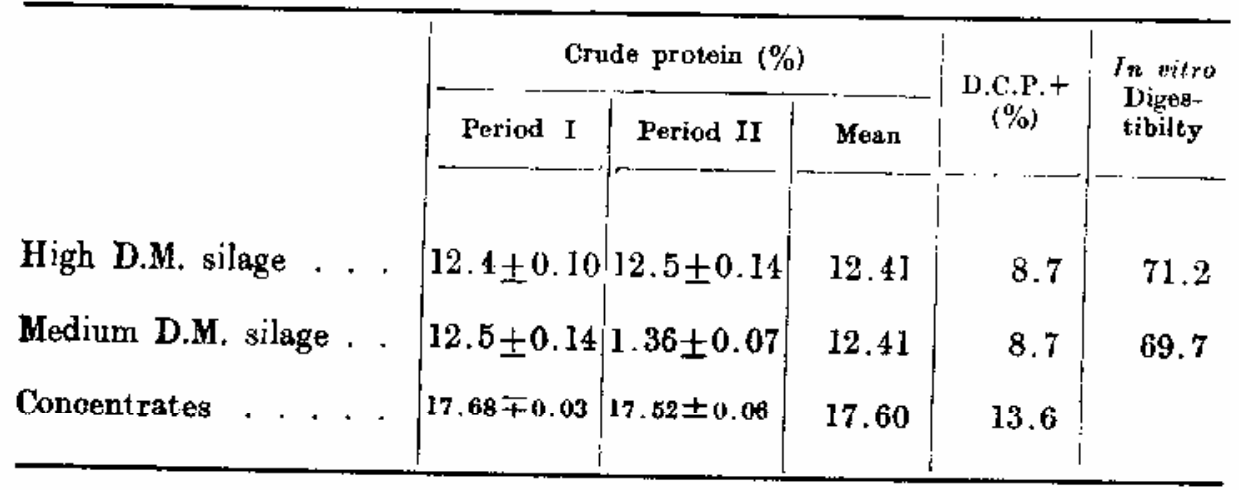

3.-The dry matter content of the experimental silages

The dry matter content of the silages used in this experiment were 56.2 and $36.6 \%$. The high D.M. material was however more cosistent in moisture content than the medium D.M. material (Coefficients of variation being I2 and $30 \%$ for he two types of silages respectively). The former was of similar dry matter content in both periods $I$ and II whereas the medium D.M. silage was significantly lower in dry matter content in the second of the two periods (Table 3 ).

TABLE 3.--DRY MATTER PERCENTAGE OF THE EXPERIMENTAI SILACES

\begin{tabular}{ll|c|c|c}
\hline Silage .ype & Period I & Period II & Mean \\
\hline High D.M. . . . . & $56.32 \pm 1.14$ & $56.05 \pm 0.67$ & $56.18 \pm 1.23$ \\
Medium D.M. . . . & $42.14 \pm 1.50$ & $30.99 \pm 1.59$ & $36.56 \pm 1.95$ \\
\hline
\end{tabular}

U.A.R. J. Anim. Prod., 10, No. 2 (1570). 
The variation in dry matter content of the medium D.M. silage was due to the rreater moisture content of the lower layers of material in the silos ; maturial that was fer in the later stages of period It. Thin variation in moisture content at different levels in the medium D.M. silo was not associated with any progressive changes in the dry matter content of the herbage during the filling of the silos, nor was it due to ingress of rain wuter as this was eflictivery excluded at all stages. It is suggrested that this difference within silos night be associated with the downward seepage of noisture being retained within the poiythene lining or the seaked silo. Part of this moisture presumably derived from respiration of the plant material during the initial stages of ensilage.

\section{4.--Management of experimental calves and feeding procedure}

The calves were housed in a byre and tied by neck in single stalls. The calves were housed seven days prior to the start of the experiment. The calves received a daily allowance of $2 \mathrm{lb}$. concentrates $(80 \%$ rolled barley $+20 \%$ decorticated groundnut cake) fed twice daily, and the silage allowances were fed three times daily in quantities which exceeded the actual intake of the calves by $15-30 \%$.

Daily samplea from silage offered and refused were taken for D.M. and crude protein determinations.

The calves were weighed at 10 a.m. on Tuesdays and Fridays of each week. Before the start of the experiment, between the two fifteen day foeding periods and at the end of the experiment weighing was preceded by a standard period of feed (24 hours) and water (12hours) withdrawal. This was intended to improve the precision of liveweight determinatione by reducing variation in the weight of feed residues in the alimentary tract (Whiteman, et al., 1954 ; Algeo, 1963).

\section{Results}

\section{1.-The intake of experimental silages}

In both periods I and II the calves receiving the high D.M. silages consumed less fresh silage than those receiving the medium D.M. silage. This differences was more evident in period II than in period I and overall was highly significant (Table 4).

The dry matter intake of the calves receiving the high D.M. silage was significantly greater than that of calve receiving the medium D.M. silage in period I ( $P$ 0.05) but this difference was not confirmed in period II. Overall, calves receiving the high D.M. silage had a marginally greater dry matter intake than the other but the difference was not significant (Table 4).

U.A.R. J. Anim. Prod., 10, No. 1 (1970). 
INILUENCE OF VAR. IN DHY MATTER ON VOLUNTARY INTAKE. 237

TABLE 4.-F FESH AND DRY MATTER INTAKE OF THE SILAGES (PER CALF)

\begin{tabular}{|c|c|c|c|c|c|c|}
\hline \multirow{2}{*}{ Silage type } & \multicolumn{3}{|c|}{ Fresh intake ( $\mathrm{kg} /$ culf / day) } & \multicolumn{3}{|c|}{ Dry matter intake ( $\mathrm{kg} / \mathrm{culf}$ / day) } \\
\hline & Period $Y$ & Period II & Mean & Period I & Period II & Mean \\
\hline High D.M. . . & 7.37 & 6.86 & 7.11 & 4.54 & 4.07 & 4.31 \\
\hline Medium D.M. . & 8.35 & 13.30 & $10.8 ?$ & 3.81 & 4.24 & 4.02 \\
\hline S.E. of Diff. & 0.58 & $0.47+++$ & $0.29+++$ & $0.23+$ & 0.11 & $0.15^{\mathrm{NS}}$ \\
\hline
\end{tabular}

2.-Silage intake in relation to liveweight :

The calves ranged in liveweight from 94 to $237 \mathrm{~kg}$. and in metabolic liveweight (L.W. 0.73) from 27 to $53 \mathrm{~kg}$. The high correlations between intake of dry matter from the two types of silage and liveweight of the calves are shown in Table 5. These indicate that 87 to $97 \%$ of individual

TABLE 5,-The RELATIONSHIP BETWEEN DRY MATTER INTAKE (Y) AND LIVEWEIGET (X-) AND MATABOLIO BODYWEIGHT 0.73

\begin{tabular}{l|c|c|c}
\hline Silage type & Linear regression equations & $\begin{array}{c}\text { Significance } \\
\text { of } \\
\text { regregsion }\end{array}$ \\
\hline High D.M. . . & $\mathrm{Y}=-1.45( \pm 1.38)+0.034( \pm 0.01) \mathrm{X}_{1}^{*}$ & +++ \\
Medium D.M. . & $\mathrm{Y}=-0.39( \pm 1.25)+0.026( \pm 0.008) \mathrm{X}_{1}^{*}$ & +++ \\
High D.M. . . $\mathrm{Y}=-2.33(+1.38)+0.16( \pm 0.019) \mathrm{X}_{2}^{* *}$ & +++ \\
Medium D.M. . & $\mathrm{Y}=-1.88( \pm 1.25)+0.14( \pm 0.044) \mathrm{X}_{2}^{* *}$ & +++ \\
\hline
\end{tabular}

* The dilference between the two regression coefficient is significant $(\mathrm{P}<0.05)$.

** The difference between tho two regreseion onefficicnt is not significant $(1>0,05)$.

variation in dry matter intake was associationed with variation in liveweight. Table 6 presents the regression equations with standard diviations of the relationship between dry matter intake and liveweight, Figures 1, 2 also illustrate this relationship. These indicates that variation in dry matter intake was closely associated with variation in liveweight per se and that adjustment of liveweight to estimated metabolic body size did not improve the closeness of this relationship; in the case of high D.M. rather the reverse.

U.A.R. J. Anim. Prod., 10, No. 2 (1970). 
TABI.E 6.-CORRELATION BETWEEN THE INTAKE OF SILALE JRY MAT'L'ER AND THE LIVEWEIGHT OF CALVES

\begin{tabular}{|c|c|c|}
\hline \multirow{2}{*}{ Silikge type } & \multicolumn{2}{|c|}{ Silage D.M. intake } \\
\hline & L. Wt. & L. Wt. 0.73 \\
\hline Higlı 1).H. . . . & $0.985++t$ & $0.986 t+t$ \\
\hline Budiun D.Ji. . . . & $0.932+t+$ & $0.934+1+$ \\
\hline
\end{tabular}

Regression analysis of dry matter intake on liveweight was also carried out after logarithmic transformation of the intakes and weights. The regression cocfficient from this analysis gave estimate of the appropriate exponent of hiveweight in the equation D.M.I. $=a($ L.W t. $) ~ k$; the value of $k$ was simitar witil boh type of silage, $1.17 \pm 0.055$ and $1.17 \pm 0.054$ for high and medium D.M. silage respectively.

The effect of silage treatment on dry matter intake of the calves has also been analysed after adjustment for variation in their liveweight. The results are presented in Table 7 . The calves receiving the high D.M. silage corsumed more silage dry matter per unit of liveweight than those receiving the medium D.M. silage in both periods $I$ and II and the calves changing from high to medium D.M. silage slightly reduced their intake, whereas those changing from medium to high D.M. silage slightly incrased their intake (Table 7). These differences however did not attain significance on either within or between period basis $(P>0.05)$.

TABLI 7.....SILAGE DRY MATTER INTAKE (KG) PER 100 KG. OF LIVEWEIGHT

\begin{tabular}{|c|c|c|c|c|}
\hline Silage type & & Period I & Period II & $\begin{array}{c}\text { Mean } \\
\text { Period I and II }\end{array}$ \\
\hline High D.M. . . & . & $2.60(3.10)$ & $2.41(2.91)$ & $2.56(3.00)$ \\
\hline Medium is. M. & . . & $2.33(2.83)$ & $2.37(2.87)$ & $2.35(2.85)$ \\
\hline S.E. of Diff. & . & $010_{N}$ & 0.08 & 0.07 s \\
\hline
\end{tabular}

Note.-lotal dry natter intakes shown thus ().

\section{3.-Liveweight changes}

Because of the short experimental periods, the records of liveweight were not sufficient to permit any precise determination of the effects of treatment on this parameter.

T.A.R. J. Anim. Prod., 10, No. 2 (1970). 


\section{Discussion}

Intake in relation to dry matter content

In both periods I and II the calves receiving the medium D.M. silage consumed more fresh silage than those receiving the high D.M. silage and this difference was more marked and very highly signilicant in the second period. This was associated with the lower dry matter content of the medium silage ; a feature recognised in other experiments (Murdoch, 1960; Byers, 1965).

Examination of dry matter intake in relation to dry matter content of the silage which was 36.6 and $56.6 \%$ on average indicates that dry matter consumption was $9 \%$ higher with the high D.M. silage than with the medium D.M. silage $(2.56 \mathrm{~kg}$. $/ 100 \mathrm{~kg}$. liveweight $\mathrm{V} 2.35 \mathrm{~kg} / 100 \mathrm{Kg}$ liveweight respectively), but this difference was not quite significant. However it was also evident that when calves fed medium D.M. silage in period 1 were changed to high D.M. silage in period II their dry matter intake per $100 \mathrm{~kg}$ liveweight increased by 3 per cent, whereas when those fed high D.M. silage in period I were changed to medium D.M. silage their dry matter intake per $100 \mathrm{~kg}$ liveweight decreased by 10 per cent. Gordon et al. (1965), observed that on silage with $43 \%$ dry matter, the lactating cows consuming $2.251 \mathrm{~kg} / 100$ $\mathrm{kg} \mathrm{L.Wt}$. increased their consumption by 10 per cent when fed silage with $65 \%$ dry matter.

Tahle 8 presents a eummary of other experiments reported in the literature about the relationship between dry matter intake and dry matter content of the silage. These experiments describe average 'long-term' (i.e. over feeding period of 10 days or more) effects of silage moisture content. on dry matter intake by livestock, and it is generally accepted that in this content the effects of variation in moisture content are mediate by their influence on the type of fermentation the material undergoes during ensilage: (Murdoch, 1967) and not attributable to moisture content per (Moore, et al., 1960).

TABLE 8.-DRY MATTBR INTAKE IN RERLATION TO DRY MATTER CONTENT OF TBE STLAGE

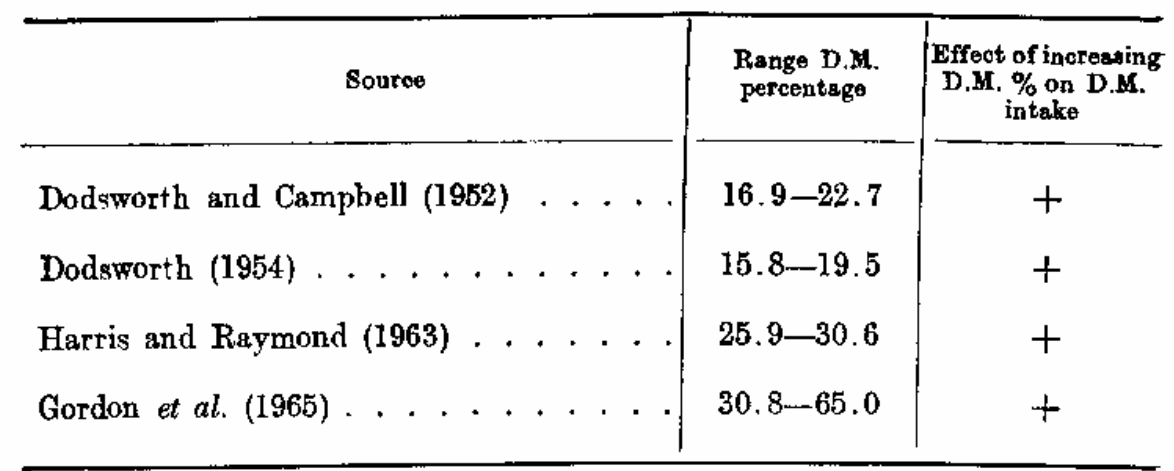


In the present experiment there was an opportunity to examine 'short-term' variations in silage intake associaled with variation in the moisture content of the silizge which had arisen alter or during ensilage. Variation considered to be associated with the movement of free water within the silage mass.

There was a close relationship between daily variation in the moisture content of the medium dry matter silage (over the range 18-48) and the intake of fresh material; when moisture content of the silage was high the intake of fresh material increased but not sufficiently to maintain the same dry matter intake as was attained on silage with a lower moisture content. This must presumably be largely associated with immediate filling effects of the fresh silage in the rumen having an influence on the amount eaten over a particular 24 hour period and to a lesser extent mediated through variation in rate of passage of material through the rumen, since the variation in the latter respect would presumably be evident only over a longer period of 2 to 3 days (Balch and Campling, 1962).

\section{Dry matter intake in relation to body weight}

Strong positive correlations were obtained when the silage dry matter intake was regressed on the liveweight and metabolic liveweight (L.Wt. 0.73). 'Chese correlations indicate that for high and medium D.M. silage respectively 17 and $87 \%$ of individnal variation in D.M. intake of the calves was associated with variation in liveweight. McCullough (1961), found that the livewreight explained $43 \%$ if the variation in silage dry matter intake of lactating cuws. The difference between calves and lactating cows could be explained by the fact that with lacting cows factors other than liveweight such as stage of lactation and milk yield affect silage intake (McCullough, 1961 ; Holmes, 1961).

The regression of dry matter intakes on calf liveweight revealed that dry matter intake of the medium D.M. silage increased by $2.6 \mathrm{~kg}$ for every $100 \mathrm{~kg}$ increase in liveweight, whereas for the high D.M. silage the increase was $3.4 \mathrm{~kg}$ D.M. $/ 100 \mathrm{~kg}$ liveweight and the difference was sigificant. The value for high D.M. silage with $(3.4 \mathrm{~kg} / 100 \mathrm{~kg} \mathrm{~L}$.Wt. $)$ obtained by Martine ot al. (1955).

Logarithmic transformation of dry matter intakes and liveweights data indicated that for every $100 \%$ increase in calf liveweight their dry matter intake of silage (of both types) increased $117+5.4 \%$. A similar value of $116+37 \%$ was obtained by Hadijpieris et al. (1965), with growing wethers; with older sheep the same workers found values of $97+17 \%$ and $85+24 \%$ which were close to 100 but not significantly different to $73 \%$. In most studies dry matter intake has usually been found to increase only $66-75 \%$ as much as liveweight (Blaxter et al., 1961). The reference base of L.Wt. 0.73 was one calculated by Brody (1945) and relates to changes in basal metabolism with differences in size between mature animals of different epecies and was shown by Brody to be inappropriate to growing animale

U.A.R. J. Anim. Prod., 10, No. 2 (1970). 
within a species. Holmes et al. (1961) and Hodgson and Wilkinson (1967), recognised a difference in the relationship between organic matter (O.M.) intake from grazing and liveweight in cows compared with heil'ers and calves. The liveweight exponent relating these two features increased in size when cows were excluded from the data; viz :

Holmes et al. (1961) :

Cows, Heifers and calves D.O.M.I. $=$ a L.Wt. 0.43

Cows, Heifers and calves D.O.M.I. $=$ a L.Wt. 0.62

Hodgson and Wilkinson (1967) :

Cows, Heifers and calves O.M.I. $=$ a L.Wt. 0.61

Cows, Heifers and calves O.M.I. $=$ a L.Wt. 0.71

In both these experiments small numbers of animals were involved and separate equations were not derived for calves, (which were comparable in size with thos used in this study). However, Holmes et al. (1961), concluded that their equations implied some change in the rolationship of intake to size at weights lower than $400 \mathrm{lb}$. This seems likely in that the rumen develops relatively faster than liveweight in the young animal (Large, 1964) whereas at a later stage of development extention of runmen size proceeds relativly mor slowly. Such dvelopment is appropriate to the young ruminant if it is to obtain a sufficient nutrient supply from bulky feeds of low energy density. In the present study it is notable that variation in chronological age, the lightest calves were 8 months younger than the heaviest calves these differences may have influenced the relationship between the variation in feed intake and liveweight.

\section{REFERENCES}

ALaxo, J.W. (1963), J. Anim. Sci, 27, 531.

Batoi, C.C. and Camplno, R.C. 1962), Nutr. Abstr. \& Rev. 3*, 669.

Blaxter, K.L., WainmaN, F.W. axd Wifson, R.B. (1901). Anim. Prod. 3, 51.

Brody, \&. (1945). "Bioenergetics and Growh". Roinhold, New York.

BYnRs, J.H, (I965). J. Dairy Sci. 48, 208.

Donsworth, T.L. (1954). J. Agric. Sci, 44, 383.

Dodsworth, T.L. and Campbul, W.H. Mc. K. (1952), Nature, London 120, 340.

Freer, M, Campling, R.C. and Balch, C.C. (1961). Brit. J. Nutr. 16, 279.

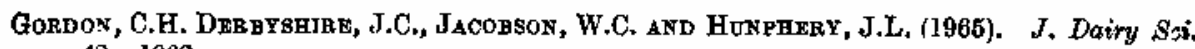
48, 1062 .

Hadipinng, G., Jones, J.G.W. And Holmes, W. (1966). Anim. Prod. 1, 309.

HaRRIs, C.E. AYD RAYMOND, W.F. (1963). J. Brit. Gratsl. Soe. 18, 204.

U.A.R. J. Anim. Prod., 10, No. 2 (1970). 
Hodggon, J., and Wilktnson, J.M. (1967). Anim. Prod. 9, 365.

Holmes, W., Jones, J.G.W. Awd Drake-Brockman, R.M. (1961). Anim. Prod. 3, 251. Large, R.Y. (1964). Anim. Prod. 6, 169.

Martin, C.M. Branson, W.F. and ReId, J.T. '1955). J. Dairy Sci. 38, 181.

MoCollodgr, M.E. (1961). J. Anim. Sci. 20, 288.

Mooke, L.A., Thomag, J.W. aNd Syens, J.F. (1960), Proe. Bth. Int. Grasel. Congr. p. 70L.

Morgan, D. (1963). N.A.A.S. Quart. Ret. 5o, 68.

MURpock, J.C. (1960). J. Brit, Grassl. Soc. 15, 70.

- (1904). J. Brit. Grasel. Soc. 19. 316.

--, (1966). Outlook Agric. 5, 17.

- - (1967). J. Brit. Grass. Soc. $28 \%$.

Pratt, A.D. and Conrad, H.R. (1967). Ohio Agric. Rea. Devel. Centre Res. Bull. 998.

Thomas, J.W., Mooke, L.A. AND Sykes, J.F. (1961). J. Dairy Sci. 44, 862.

Whitrmas, J.B., Loggiss, P.F. and Chambers, D. (1964). J. Anim. Sci. 13, 832.

WirRTNGa, G.W. (1960). Proc. 8th Intr. Grassl. Congr. p. 497. 
INFLI HNCW OW VAR. IN DRY MATYER ON VOLUNTARY INTAKE. 243

\section{تأثير التباين فى المادة الجافة بالسيلاج المعطن على قابلية الكيوان لتناوله الدكنود ابراميم رفعت}

\section{املنغص}

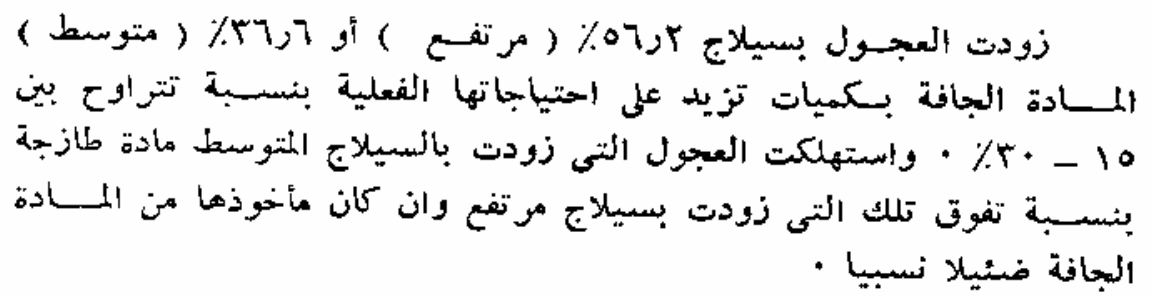

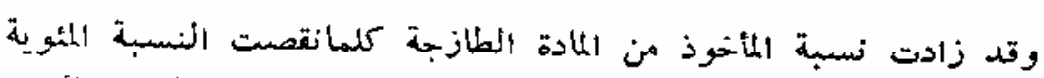

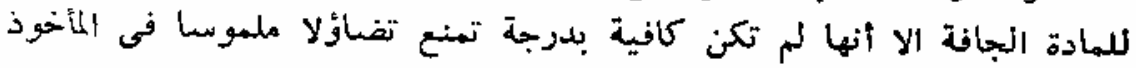
من المادة الجافة الجافة

وكان التباين في المأخوذ من الملادة الجافة فى العلف بين أفراد العجبال

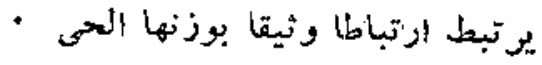

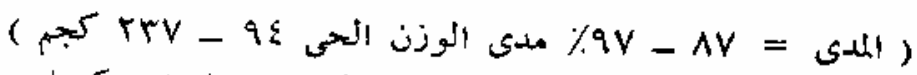

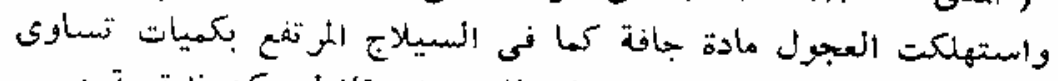

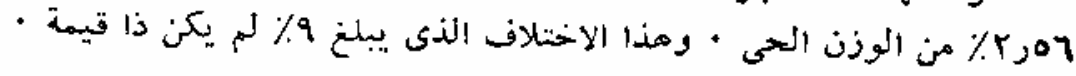

